\section{An F-Type Potato Virus in Australia}

THE $F$-type of potato virus recently described by Clinch, Loughnane and Murphy ${ }^{1}$ and Murphy and Loughnane $^{2}$ is evidently widely distributed. At Canberra in January 1936 a virus which was carried without symptoms in a number of solanaceous hosts was recovered from potatoes with a slight aucuba mottling of the foliage. The variety of potato was supplied under the name Arran Crest, but its characters were rather those of Arran Pilot. No tuber necrosis was noticed. The virus was recovered a number of times over a period of a year from the tubers of these plants, and from second generation plants grown from the tubers. The presence of the virus did not protect the potato plants from infection with $Y$-type viruses, and various other hosts containing it were infected with $X$ virus and $X+B$ without difficulty. It caused severe necrosis on pepper at mean temperatures below about $70^{\circ} \mathrm{F}$.; above that, and at temperatures too low for the strong growth of pepper plants, the symptoms were milder. Solanum nigrum was found to be an important host on which the virus sometimes produced a very faint and transitory vein-clearing or mottle, but generally no symptoms at all. It could, however, be recovered from apparently unaffected plants in high concentration.

So far as they were studied, the properties of the Australian virus corresponded with those of the $F$-type. Whether this group is important in Australia is not yet known, although viruses causing necrosis of pepper have been recovered from several sources.

Division of Plant Industry,

J. G. BALD.

Council for Scientific and

Industrial Research,

Canberra.

March 2.

${ }^{1}$ Clinch, Phyllis, Loughnane, J. B., and Murphy, P. A., Sci. Proc. Roy. Dublin Soc., 21, 431 (1936).

${ }^{2}$ Murphy, P. A., and Loughnane, J. B., Sci. Proc. Roy. Dublin Soc., 21, 419 (1936).

\section{Interfertility Phenomena of the American and} European Forms of Panus stypticus (Bull.) Fries*

Panus stypticus (Bull.) Fries is a small coriaceous agaric which grows usually on the wood of deciduous trees, and is found both in Europe and North America. Although alike morphologically, a striking difference exists between the American and European forms, namely, the former is luminous and the latter is non-luminous ${ }^{1}$. Since they were known to differ in this character, a study of the two forms in relation to their pairing reactions and the method of inheritance of the factor for luminosity was undertaken.

Monosporous mycelia were isolated from single fruit-bodies of Panus stypticus collected at Timagami, Ontario; Ottawa, Ontario; and Lake MacDonald, Quebec (in Canada); at Dresden, Darmstadt and Potsdam (in Germany); at Sigless in Austria ; and at Wageningen in Holland. Series of pairings in all possible combinations of monosporous mycelia from each of these fruit-bodies have shown that both the American and European forms of this fungus are heterothallic and tetrapolar. These results were published in the Progress Report of the Dominion Botanist for the years $1931-34^{2}$, and have been confirmed by Vandendries' work with the European form? ${ }^{3}$.

* Contribution No. 491 from the Division of Botany, Experimenta Farms Branch, Department of Agriculture, Ottawa, Canada.
By pairing monosporous mycelia derived from different sources, it has been found that both the American forms and the European forms are fertile among themselves and that the American form is completely interfertile with the European form ${ }^{2}$ (Fig. 1).

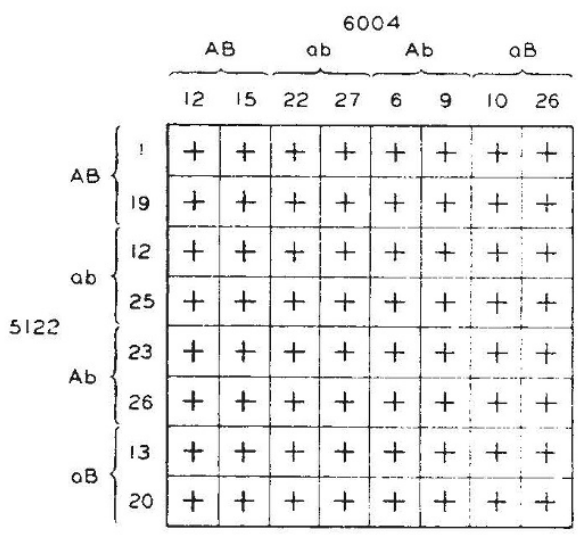

Fig. 1.

TABLE SHOWING THE RESUlTS OF PAIRING EIGHT MONOSPOROUS MYCELIA OF THE LUMINOUS AMERICAN FORM OF Panus stypticus, +6004, AND EIGHT MONOSPOROUS MYCELIA OF THE NON-LUMINOUS EUROPEAN FORM, +5122 . THE PLUS SIGN INDICATES THE PRESENCE OF CLAMP CONNEXIONS.

In sixty-eight pairings of monosporous mycelia of the luminous American form with the non-luminous European form, the diploid mycelium produced has been isolated and found to be luminous; that is, in the mycelium of the $F_{1}$ generation, luminosity is dominant. If sporophores are obtained from these paired cultures, the monosporous mycelia from them will be tested to determine the method of inheritance of the factor for luminosity in the $F_{2}$ generation.

Ruth Macrae.

Division of Botany,

Central Experimental Farm, Ottawa.

1 Biller, A. H. R., "Researches on Fungi", 3, 408 (1924).

2 Macrae, R., Rept. Dominion Botanist, 1931-1934, 60 (1935).

3 Vandendries, R., Bull. Sor. myr. France, 52, 54 (1936).

\section{Water and Fat Content of Tsetse Flies}

IN his recent letter to NATURE on this subject ${ }^{1}$ Mr. R. W. Jack emphasizes the importance of excluding the weight of fat in tsetse flies when calculating the percentage of water found in them.

I came to the same conclusion early in 1935, and communicated my opinion to Prof. Buxton in a letter dated April 2 of that year. My complete findings for 1935, when more than 800 flies were examined by me, were published in $1936^{2}$.

In Table 1 my results for 1935 are summarized. It will be observed that with increasing hunger the percentage of water in gross body weight shows a rise. But with fat eliminated from both wet and dry weights the percentage of water shows a slight fall after stage II of hunger, though the variation from stage to stage is now much less than before. The males, other than young males, are divisible into four stages of hunger by external characters-gorged, replete, intermediate and hungry. 